\title{
POLA OKUPASI GUA KIDANG, JELAJAH RUANG DAN WAKTU: Suatu Hipotesis
}

\section{OCCUPATIONAL PATTERN OF KIDANG CAVE, EXPLORATION OF SPACE AND TIME: A Hypothesis}

\author{
Indah Asikin Nurani ${ }^{1} \&$ Agus Tri Hascaryo ${ }^{2}$ \\ ${ }^{1}$ Balai Arkeologi Yogyakarta \\ 2 Jurusan Arkeologi FIB UGM \\ anikardani@gmail.com \\ agusgeoar@yahoo.com
}

\begin{abstract}
Kidang cave in the karst region Todanan, Blora, Central Java is a cave complex which consists of two caves. Archaeological findings show intensively inhabited this cave for a long time. Evidence of activity traces left behind in the form of artifacts, ekofak, features, skeleton (grave), and a fireplace. Pulling from landuse caves man and cave dwellers Kidang roaming in search of food sources and raw materials for tools, encouraging the cultural continuity with Pleistocene sites. Geological and archaeological data shed some light on the Kidang cave man roaming in the span of space and time with Pleistocene sites. A hypothesis of continuity between Pleistocene sites with Kidang cave will be formulated based on geo archaeological study.
\end{abstract}

Keywords: Kidang Cave, River Lusi, Holocene, Geological

\section{ABSTRAK}

Gua Kidang berada di kawasan karst Todanan, Blora, Jawa Tengah merupakan kompleks gua yang terdiri atas dua gua. Temuan arkeologis menunjukkan gua ini intensif dihuni dalam waktu lama. Bukti jejak aktivitas yang ditinggalkan berupa artefak, ekofak, fitur, rangka manusia (kubur), dan perapian. Menarik dari pola pemanfaatan lahan gua dan jelajah manusia penghuni gua Kidang dalam mencari sumber makanan dan bahan baku untuk peralatan, memberikan harapan adanya kesinambungan budaya dengan situs-situs kala Pleistosen. Data geologis dan arkeologis membuka titik terang jelajah manusia penghuni gua Kidang dalam rentang ruang dan waktu dengan situs-situs kala Pleistosen. Suatu hipotesis kesinambungan antara situs-situs kala Pleistosen dengan gua Kidang akan dirumuskan berdasarkan kajian geoarkeologi.

Kata kunci: Gua Kidang, Sungai Lusi, Holosen, Geologi

\section{PENDAHULUAN}

Blora merupakan salah satu wilayah penting yang memiliki potensi arkeologis berupa tinggalan budaya sejak kala Pleistosen terutama di daerah DAS Bengawan Solo hingga masa kolonial. Situs-situs Pleistosen di daerah ini antara lain situs Mulyorejo, Jigar, Ngandong, dan Medalem. Balai Arkeologi Yogyakarta mulai melakukan penelitian situs-situs Pleistosen DAS Solo daerah Blora ini pada tahun 1977 yang berhasil mengumpulkan temuan fosil binatang purba seperti stegodon, elephas, rusa, kura-kura, sapi, dan kerbau. Temuan tersebut berada satu konteks dengan tinggalan budaya alat tulang dan tanduk, serta alat dari cangkang kerang (Moeljadi, 1984). Setelah puluhan 
tahun kemudian, yaitu pada tahun 2006 - 2007 Balai Arkeologi Yogyakarta bekerjasama dengan Dinas Kebudayaan dan Pariwisata Kabupaten Blora melakukan penelitian di situs Kuwung yang merupakan situs manusia purba di DAS Bengawan Solo. Hasil penelitian di situs Kuwung dengan melakukan survei adalah sebaran fosil vertebrata dari jenis hewan gajah purba (elephantidae dan stegodontidae), banteng (bos bubalus $s p$ ), kerbau (bubalus palaeokarabau), rusa (cervidae) babi (suidae), kura-kura (testudinidae, chelonidae), badak (rhinecerus sp.), kuda nil, serta fosil binatang air seperti ikan hiu dan kerang (pelecypodae). Selain itu, juga ditemukan beberapa artefak seperti alat batu, alat tulang, dan alat tanduk. Temuan alat batu antara lain adalah: kapak perimbas, kapak penetak, batu inti, alat serpih, alat bilah, dan serut. Adapun temuan alat tulang adalah 2 (dua) lancipan dari tulang dan 1 (satu) alat dari tanduk. Fosil dan artefak yang ditemukan dalam survei sebagian besar sudah ada di permukaan tanah sebagai hasil dari penggalian liar oleh penduduk sehingga pertanggalannya tidak dapat diketahui dengan pasti. Namun, dari data geologi dapat diketahui bahwa temuan fosil berada pada formasi Kabuh dan pada endapan teras yang berumur pleistosen tengah - pleistosen atas (Gunadi, 2007).

Temuan artefak menunjukan bahwa alat-alat yang ditemukan di situs Kuwung merupakan hasil budaya fase paleolitik yang dihasilkan oleh Homo erectus pada kala Pleistosen. Adapun identifikasi alat tanduk diketahui alat tersebut memiliki teknologi yang sama dengan alat tanduk yang ditemukan di situs Ngandong, sehingga diduga alat tersebut merupakan hasil budaya dari Homo erectus progresif yang berumur Pleistosen atas. Analisis temuan fosil stegodon sp mengindikasikan, situs prasejarah di kabupaten Blora memiliki potensi temuan fosil yang hidup pada kala Pleistosen tengah yang masuk pada kategori fauna Trinil (Gunadi, 2008).

Di lain pihak, sejak tahun 2005 sampai saat ini, Balai Arkeologi Yogyakarta melakukan penelitian tinggalan budaya masa selanjutnya setelah kala Pleistosen yaitu kala Holosen. Kehidupan pada awal kala Holosen sudah semakin meningkat sesuai dengan berkembangnya tingkat kecerdasan manusia saat itu, yaitu hidup semi nomaden atau berpindah-pindah dan mengumpulkan makanan tingkat lanjut (Soejono, 2000). Mereka mulai menempati gua atau ceruk sebagai tempat tinggalnya, meskipun pola hidup mereka masih sama dengan masa sebelumnya yang mengandalkan pada ketersediaan sumber makanan dan sumber bahan baku untuk peralatan sehari-hari yang tersedia di lingkungan alam sekitarnya.

Berdasarkan hasil penelitian eksplorasi gua-gua di kawasan karst Blora, yang meliputi 4 (empat) kecamatan yaitu di Kecamatan Todanan, Jepon, Bokorejo, dan Kradenan secara arkeologis menunjukkan gua-gua yang ada tidak begitu bagus sebagai hunian pada masa prasejarah. Hal tersebut didasarkan pada pengamatan morfologi gua, sirkulasi udara dan sinar matahari masuk, temuan permukaan dan pengupasan, serta morfologi lahan sekitar gua (Nurani dan Yuwono, 2008). Sebagian besar gua yang ada di kawasan karst Blora merupakan rekahan bukit, sungai bawah permukaan, dan gua-gua vertikal (sumuran) sebagai sumber air. Ditinjau dari aspek kelayakan hunian, gua-gua tersebut tidak layak huni, selain kondisinya lembab gua-gua tersebut masih merupakan sungai bawah permukaan yang aktif, sehingga jejak-jejak aktivitas tidak tampak dari temuan permukaan dan pengupasan. Satu-satunya gua yang memiliki indikasi hunian hanya Gua Kidang. Indikasi hunian tersebut meliputi temuan permukaan berupa fragmen keramik, tembikar, cangkang moluska, dan tulang. Oleh karena itu, gua ini diteliti lebih lanjut melalui ekskavasi. Temuan hasil ekskavasi gua Kidang antara lain meliputi beberapa tipe alat dari cangkang kerang seperti: serut, lancipan, penusuk, sudip, dan perhiasan (manik-manik); serta alat dari tulang seperti: sudip, lancipan, pengasah, dan spatula. Temuan berbagai jenis artefak tersebut merupakan bukti adanya kehidupan manusia prasejarah di gua Kidang secara intensif (Nurani, 2005). Selain itu, hasil ekskavasi pada tahun 2009 memperkuat kesimpulan tersebut dengan temuan fragmen gigi dan tulang komponen rangka manusia penghuni gua Kidang, dan terakhir pada tahun 2012 ditemukan rangka utuh posisi semi terlipat orientasi timur - barat. 
Hasil penelitian gua Kidang yang sampai saat ini masih berlangsung menunjukkan situs ini semakin menarik untuk diungkap lebih lanjut. Berbagai permasalahan yang perlu diungkap lebih lanjut masih banyak, namun dalam tulisan ini sesuai dengan judul hanya akan diungkap tiga permasalahan terutama terkait dengan pola hidup manusia penghuni gua Kidang terhadap kondisi lingkungan alam sekitarnya. Ketiga permasalahan tersebut adalah sebagai berikut.

1. Bagaimana pola adaptasi manusia penghuni gua Kidang terhadap lingkungan alam sekitarnya dalam mempertahankan hidupnya?

2. Sejauh mana jelajah manusia penghuni gua Kidang dalam mencari sumber pangan dan bahan baku untuk peralatan sehari-hari?, dan

3. Bagaimana kesinambungan jelajah ruang dan waktu antara gua Kidang dengan situs-situs kala Pleistosen?

\section{GEOLOGI DAN PROSES PEMBENTUKAN GUA KIDANG}

Gua Kidang berada pada kawasan karst Todanan, Blora. Tepatnya secara administratif berada di Desa Tinapan, Kecamatan Todanan, Kabupaten Blora, Provinsi Jawa Tengah, adapun keletakan astronomis berada pada: LS $06^{\circ} 59^{\prime} 18,6^{\prime \prime}-111^{\circ} 11^{\prime}$ 50,2 " BT dengan arah hadap gua ke timur. Gua Kidang merupakan gua yang keletakannya di bawah permukaan tanah sekitarnya (luweng). Gua ini terdiri atas 2 (dua) gua yang berhadapan, selanjutnya penamaan situs gua ini adalah Gua Kidang A (arah hadap ke timur) dan Gua Kidang AA (arah hadap baratlaut).
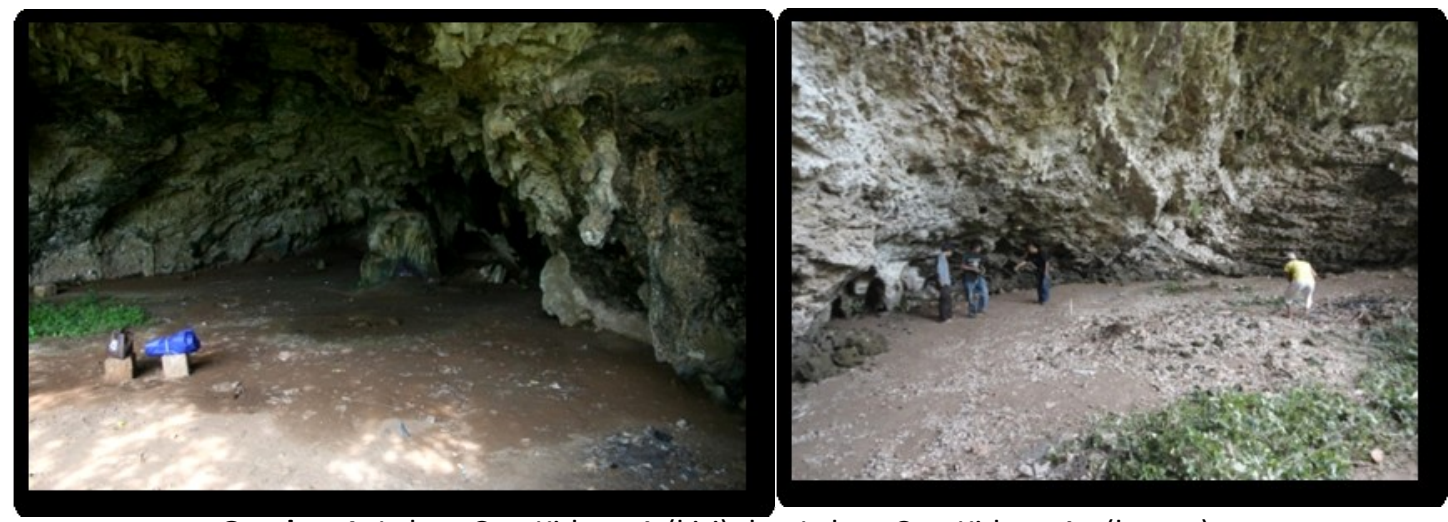

Gambar 1. Lahan Gua Kidang A (kiri) dan Lahan Gua Kidang Aa (kanan)

(Dok. Nurani)

Ekologi karst gua Kidang dan sekitarnya merupakan sungai multibasinal, luweng, tebing karst, dan sungai bawah permukaan. Sungai multibasinal yang tampak saat ini tersebar pada daerah aliran sungai Kedungwaru, Kedungwungu, dan Jaten. Ponor dan porus tersingkap di beberapa tempat sebagai bukti bahwa di lokasi sekitar gua Kidang adalah daerah aliran sungai bawah permukaan. Kelurusan luweng-luweng terhadap lokalitas gua Kidang juga membuktikan dahulu daerah ini memiliki sungai induk yang berada di bawah permukaan. Sungai bawah permukaan tersebut sebagai cikal-bakal pembentukan gua-gua di ekologis karst Todanan. Secara geologis, gua-gua yang terdapat di kawasan karst Todanan ini terletak di satuan batuan batu gamping Formasi Bulu yang bertopang pada satuan batuan Formasi Wonocolo (Nurani dan Hascaryo, 2011). Berikut peta geologi gua Kidang dan sekitarnya. 


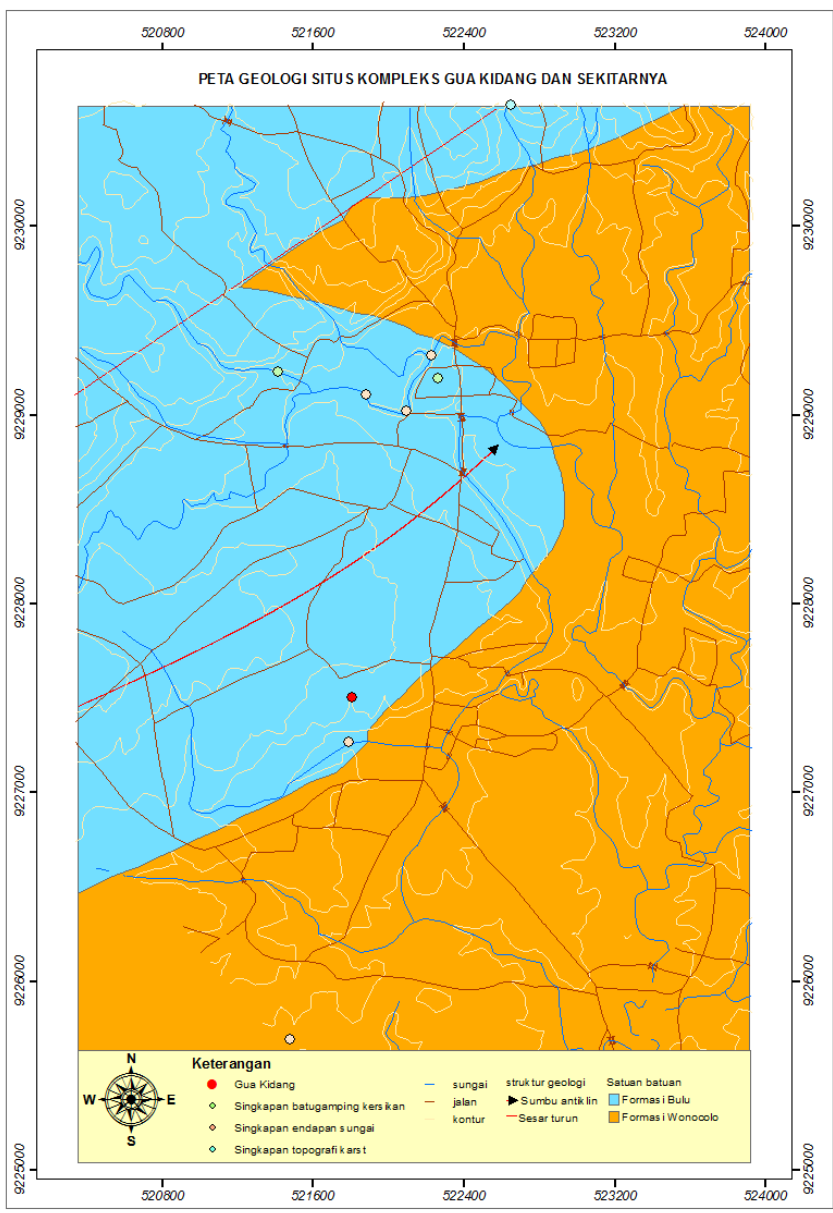

Peta Geologi situs Kompleks Gua Kidang (Hascaryo, 2011)

Kondisi geologis kawasan karst Todanan pembentukan gua-guanya disebabkan karena perkembangan sungai bawah permukaan. Menarik untuk dikaji lebih lanjut adalah proses pembentukan gua-gua terutama proses pembentukan gua Kidang, mengingat gua ini sampai saat ini merupakan satu-satunya gua yang memiliki indikasi hunian di kawasan karst Blora. Selain itu, berdasarkan kajian tersebut dapat diketahui proses hunian sejak gua Kidang ini digunakan sebagai tempat hunian sampai akhirnya ditinggalkan dan tidak termanfaatkan lagi sebagai hunian.

Formasi Wonocolo di daerah gua Kidang dan sekitarnya, memiliki ciri megaskopis yang tampak pada singkapan, yaitu jenis batugamping kalkarinit fragmental. Struktur sedimen berlapis berukuran $25-30$ $\mathrm{cm}$, semakin ke atas ketebalan per lapisan semakin besar mencapai 60 cm berwarna putih kecoklatan. Kekarkekar tampak berkembang pada atap dan dinding gua. Perkembangan stalaktit, dripstones, flower stones, dan flow stone cukup baik, terutama di bagian ruangan jalur sungai utama.

Keruangan gua Kidang merupakan kompleks gua, berawal dari aliran sungai utama bawah permukaan dan percabangan anak sungainya. Keberadaan aliran sungai mempengaruhi proses pelarutan horisontal dan vertikal pada satuan batuan batugamping. Pelarutan dan pengikisan terjadi terus menerus walaupun tingkat intensitas berubah-ubah sesuai dengan keadaan iklim pada saat itu. Semakin lama proses tersebut berlangsung menyebabkan pembentuk lorong aliran akan semakin besar pula. Aliran sungai mengalir dari arah barat-timur. Percabangan sungai menyatukan anak sungai yang berasal dari arah utara dengan sungai induknya. Kedua aliran sungai tersebut kemudian ke luar ke permukaan melalui ponor yang berada di sisi timur gua ini. Keberlangsungan penambahan luas lorong air bawah permukaan menyebabkan semakin tipisnya dinding dan atap gua. Sementara itu, air vadus dan air run off yang berasal dari air hujan masuk ke dalam ruang bawah permukaan melalui pori-pori batu gamping dan kekar-kekar atau rekahan. Laju air vadus maupun run off pada alur pori dan rekahan tidak hanya menyebabkan erosi vertikal tetapi juga pelarutan $\mathrm{CaCO}_{3}$. Seperti halnya aliran sungai bawah permukaan, baik air vadus maupun run off semakin lama akan semakin tinggi intensitas pelarutannya. Kondisi tingkat erosi horisontal dan vertikal yang disebabkan oleh air aliran bawah permukaan dan lebih intens oleh bantuan air vadus dan run off menyebabkan tingkat penipisan pada dinding serta atap gua sangat tinggi. Selanjutnya bagian bawah lorong terbentuk tandon air pada percabangan sungai. Tandon ini pun semakin lama semakin besar ukurannya.

Penipisan sangat intensif terjadi pada bagian atap lorong yang dipengaruhi pula oleh kerapatan kekar, sehingga bagian ini pertama kali mengalami keruntuhan. Bukti yang tampak di lokasi sekitar gua Kidang adalah bagian utara atau di atap aliran anak sungai yang saat ini berupa ceruk gua. Runtuhnya atap gua mengubah bentuk lorong 
aliran bawah permukaan yang awalnya sebagai tandon kemudian berubah menjadi chamber (ember). Mulut chamber semakin lama semakin besar bersamaan dengan kelangsungan proses pelarutan, erosional, dan peruntuhan atap lorong. Awal reruntuhan di sekitar anak sungai menyebabkan penghambatan aliran hingga pada suatu saat aliran ini berhenti dan tidak berfungsi sebagai aliran bawah permukaan. Namun, aliran sungai utama masih berlanjut walaupun terjadi penghambatan arus. Bagian dasar lorong anak sungai yang telah menjadi ceruk akan menjadi tempat akumulasi sedimentasi. Pembentukan daratan pun mulai terjadi pada saat itu. Material-material lepas berukuran pasir halus-lanau yang berasal dari luar mengendap di lantai gua dengan bantuan media angin. Kondisi demikian berlangsung dari waktu ke waktu, hingga kondisi dasar aliran anak sungai seluruhnya menjadi daratan.

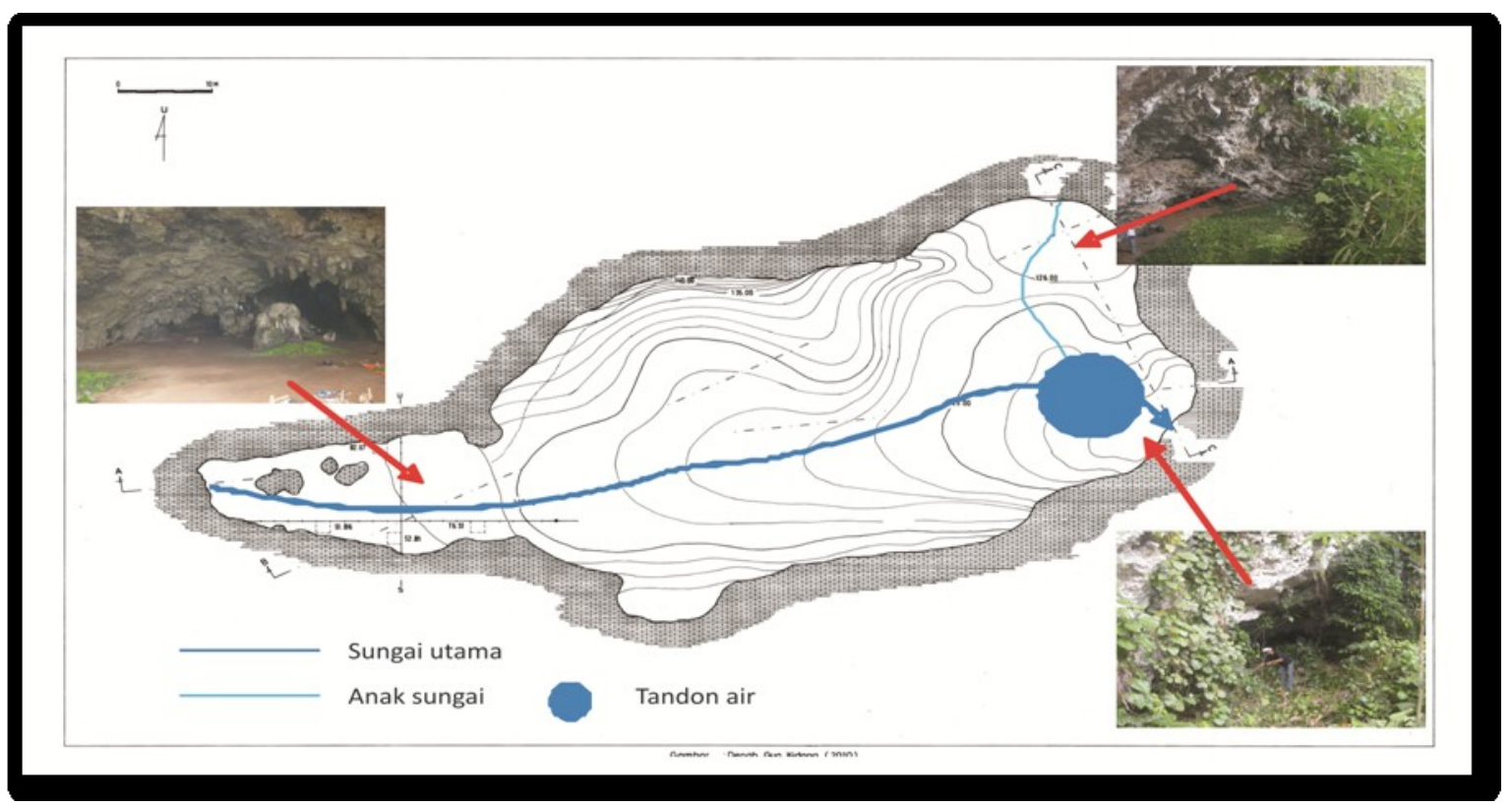

Gambar 2. Awal Aliran Air Bawah Permukaan DAS Gua Kidang

Lorong sungai utama masih terus berfungsi sebagai aliran sungai namun intensitas aliran sudah mengalami penurunan. Begitu pula aliran sungai bawah permukaan mengalami penurunan debit air akibat sedimentasi atau penghambatan aliran oleh material runtuhan atap dan dinding. Pembukaan atap, juga masih terus berlangsung dengan proses reruntuhan bagian atas lorong terutama di bagian barat hingga pembentukan mulut gua. Runtuhnya atap lorong di bagian timur mengakibatkan perlebaran mulut chamber, sehingga lokasi gua Kidang semakin terbuka. Air vadus dan run off yang membawa material agregat tanah yang berukuran pasir halus - lanau lebih banyak masuk dan mengendap di dalam gua. Hal ini menyebabkan proses pembentukan daratan berjalan cepat hingga menutupi semua dasar sungai bawah permukaan. Sungaisungai yang semula berair menjadi tertutup dan tak berair. Saat keadaan gua telah menjadi daratan, lahan mulai dapat dimanfaatkan sebagai hunian dengan segala aktivitasnya (Gambar 3). 


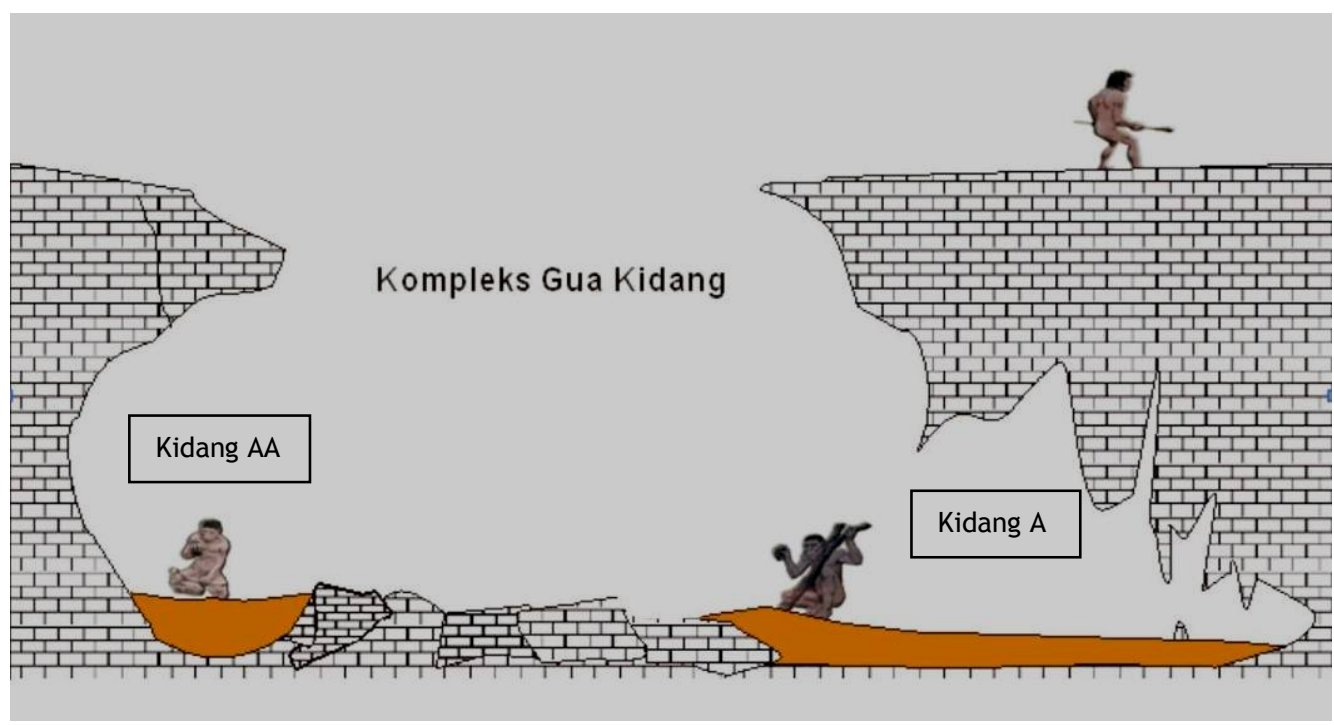

Gambar 3. Ilustrasi Okupasi Pemanfaatan Lahan Kompleks Gua Kidang

\section{POLA HIDUP PENGHUNI GUA KIDANG}

Hasil penelitian gua Kidang melalui ekskavasi pada 6 kotak di gua Kidang A dan sebuah kotak di gua Kidang AA berukuran 1,5 x 1,5 m sampai tahun 2011, dapat disimpulkan beberapa hal sebagai berikut (Nurani dan Hascaryo, 2011).

1. Pola adaptasi manusia penghuni gua Kidang dalam mempertahankan hidupnya adalah dengan penjadwalan musim (lingkungan bertemperatur rendah (musim kering) dan lingkungan bertemperatur tinggi (musim basah)) untuk menentukan jenis konsumsi pangan. Pada musim kering mereka mengkonsumsi binatang invertebrata yaitu jenis kerang dan siput, sedangkan pada musim basah (lingkungan bertemperatur sedang - tinggi) mereka mengkonsumsi binatang jenis vertebrata. Asumsi tersebut diperkuat dengan bukti stratigrafi yaitu pada lapisan atas temuan ekskavasi didominasi oleh cangkang moluska spesies kerang dan siput baik berupa artefak maupun ekofak (sisa makanan), sedangkan pada lapisan bawah didominasi temuan berupa tulang binatang darat terutama jenis vertebrata baik artefak maupun ekofak. Selain itu, berdasarkan proses pengendapan membuktikan pada lapisan bawah terjadi penggumpalan dengan tingkat kelembaban sedang. Proses pengendapan tersebut disebabkan kondisi tanah basah.

2. Teknologi yang diterapkan dalam pembuatan alat dari cangkang kerang dan tulang menunjukkan tingkat teknologi relatif "maju" dibandingkan teknik pengerjaan alat kerang dan tulang temuan dari gua-gua lainnya di Jawa. Selain dari segi teknik pengerjaan, jenis alat atau perhiasan yang diproduksi juga memiliki variasi dan tipe yang lebih beragam dibandingkan dengan temuan alat dan perhiasan cangkang kerang dan tulang dari gua-gua di Jawa lainnya. Dari bahan cangkang yang digunakan untuk peralatan menunjukkan juga pemanfaatan yang maksimal, tidak hanya dari cangkang class pelecypoda, tetapi juga dari class gastropoda. Hal tersebut sampai saat ini belum ditemukan di guagua hunian di Jawa. Adapun alat dari batu atau litik tidak berkembang dengan baik, umumnya alat litik dibuat untuk kebutuhan mengasah cangkang dan tulang sehingga teknik-teknik pangkasan sebagaimana dalam pembuatan serpih - bilah tidak ada. Selain itu, bahan baku batu yang tersedia di sekitar gua dan lingkungan sekitar tidak menyediakan bahan batu dengan silikaan tinggi. Diduga 
sumber bahan baku terdekat didapatkan dari DAS Solo yang merupakan lokasi situs-situs kala Pleistosen. Meskipun kedudukan alat batu bukan sebagai alat utama, namun adanya jenis batu dengan silikaan tinggi (antara lain rijang merah dan kuning) menunjukkan bahwa manusia penghuni gua Kidang telah mengeksplorasi alam sampai ke DAS Solo. Selain itu, berdasarkan teknologi yang diterapkan pada pembuatan alat dan perhiasan dari cangkang kerang dan tulang, tampaknya penerapan teknologi litik dilakukan.

3. Jenis binatang yang dikonsumsi manusia penghuni gua Kidang terdiri atas spesies invertebrate (moluska) baik dari air tawar maupun laut dan spesies vertebrata antara lain jenis cervidae, suidae, macaca, bovidae, dan rodentsia. Temuan yang menarik dari jenis binatang adalah fragmen gigi stegodon dan elephas di kotak B2U7. Kedua jenis binatang ini habitat terdekat diduga berada di sekitar Bengawan Solo (situs Kuwung, Jigar, Manden, dan Ngandong di Blora bagian tenggara) yang merupakan situs manusia purba kala Pleistosen; Situs Pati Ayam, Kudus; dan situs Sangiran. Apabila dugaan tersebut benar, maka jangkauan jelajah manusia penghuni gua Kidang tersebut mencapai jarak sekitar $50 \mathrm{~km}$. Berdasarkan temuan tersebut menarik untuk ditelusuri apakah terdapat lokalitas jelajah manusia penghuni gua Kidang bereksplorasi dalam mempertahankan hidupnya yang lebih dekat selain situs-situs tersebut di atas?.

Berdasarkan hasil penelitian sampai tahun 2011 tersebut di atas, tampak jelas terdapat dua hal yang perlu ditelusuri lebih lanjut. Kedua hal tersebut adalah data lapisan tanah (stratigrafi $\rightarrow$ waktu) yang mencerminkan adanya pola makan sesuai temperature lingkungan (rendah $\rightarrow$ musim kering mengkonsumsi invertebrate dan tinggi $\rightarrow$ musim basah mengkonsumsi vertebrata) dan jangkauan jelajah manusia dalam mempertahankan hidup (ruang). Terkait dengan jangkauan jelajah manusia dalam mencari lokasi sumber pangan dan sumber bahan baku untuk peralatan, maka dilakukan survei pada lokasi yang lebih dekat dari $50 \mathrm{~km}$ sebagaimana yang telah diasumsikan sebelumnya. Lokasi tersebut adalah di teras sungai Lusi, yang secara administratif terletak di Kabupaten Grobogan sebelah baratdaya gua Kidang.

Hasil survei di teras Sungai Lusi membuka harapan baru sekaligus temuan situs baru terkait jejak manusia purba Kala Pleistosen. Areal survei dipilih di daerah meander sungai Lusi yang terletak di Dusun Dumpil, Desa Ngaringan, Kecamatan Ngaringan, Kabupaten Grobogan. Tujuan dari survei adalah melacak keberadaan jenis-jenis temuan hasil ekskavasi yang secara geologis tidak terdapat di sekitar situs kompleks Gua Kidang. Temuan-temuan tersebut meliputi binatang species elephas, stegodhon, dan kerang laut, serta bahan baku untuk peralatan sehari-hari yaitu batu bersilikaan tinggi seperti chert atau rijang.

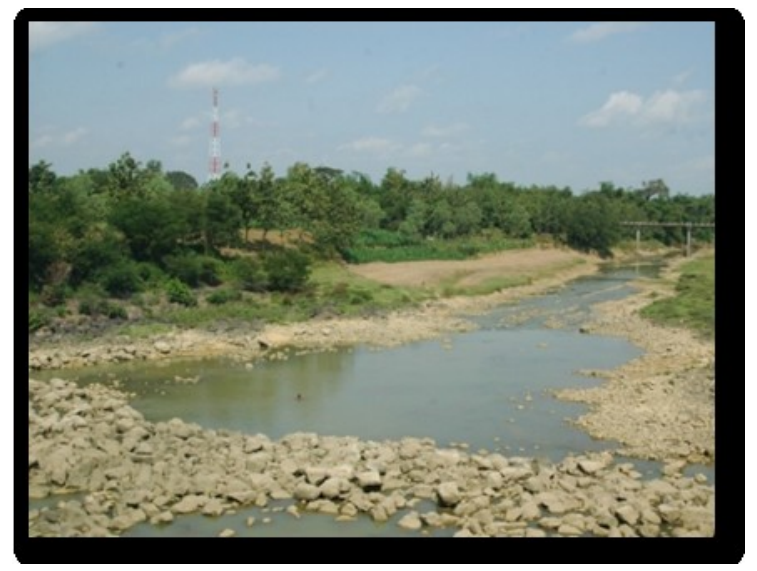

Foto 1. Sungai Lusi 
Selain bertujuan melacak jelajah manusia penghuni gua Kidang yang terdekat dalam mencari sumber makanan dan sumber bahan baku untuk peralatan, sekaligus untuk merunut kesinambungan budaya cikal bakal penghuni gua Kidang. Dalam hal ini adalah manusia pendukung budaya kala Pleistosen. Meander sungai Lusi yang terletak di Kabupaten Grobogan merupakan daerah yang kini dimanfaatkan sebagai bendungan. Beberapa singkapan lapisan tanah menunjukkan formasi Tambakromo dan grenzbank. Temuan yang berhasil dikumpulkan antara lain meliputi fosil buffelus bubalus (dari berbagai bagian tulang), fosil plastron geoselon, gigi ikan Hiu, batu rijang, cangkang kerang laut, artefak dari tulang, dan kapak perimbas.

\section{PROSES PENGENDAPAN SEDIMENTASI GUA KIDANG}

Dalam mengungkap permasalahan jelajah manusia penghuni gua Kidang skala waktu (vertikal), maka perlu dijabarkan sejarah pengendapan sedimentasi yang didasarkan lapisan tanah (stratigrafi) hasil ekskavasi. Lapisan tanah terlengkap dalam hal ini adalah di kotak B2U7. Berdasarkan lapisan tanah B2U7, diketahui bagaimana sejarah pengendapan sedimentasi yang terjadi di gua Kidang. Urutan stratigrafi dari tertua (lapisan 4) hingga termuda (lapisan 1) proses pembentukkannya adalah sebagai berikut (Nurani, Hascaryo, dan Koesbardiati, 2012).

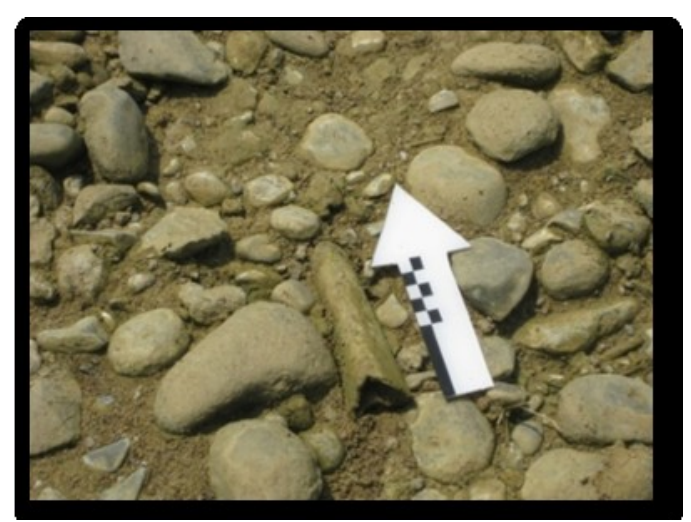

Foto 2. Artefak Tulang

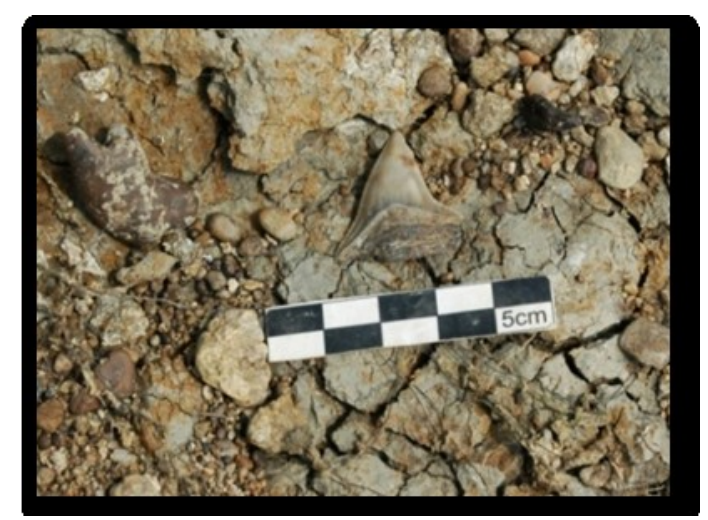

Foto 3. Gigi Ikan Hiu

Lapisan 4 memiliki ciri-ciri fisik material pasir lempungan dengan ciri megaskopis. Berwarna abu-abu kehitaman, kekompakan rendah, dan porositas sedang. Semen pengikat antarbutir berupa larutan $\mathrm{CaCO}_{3}$ (karbonat) dengan struktur sedimen massif, sedangkan struktur material endapan lapisan tampak berbentuk geluh. Berdasarkan skala wenthwoth menunjukkan ukuran butir pasir sangat halus. Fragmen berupa batu gamping berukuran kerikil yang mengambang pada masa dasar. Nodul dan lensa pasir lanauan berwarna coklat kemerahan tampak di semua dinding. Hal ini menunjukkan bahwa adanya intrusi dari lapisan pasir lanauan. Pada bagian bawah lapisan 4 terdapat beberapa fragmen tulang binatang yang berwarna kehitaman. Kenampakan lapisan yang menyebabkan berwarna kehitaman adalah karena sistem hidrologi yang buruk pada saat itu dan terjadi setelah pembentukan lapisan ini. Pembusukan bahan organik terjadi lebih intensif akibat kandungan air yang cukup tinggi dan mengakibatkan pula peningkatan kelembaban semakin tinggi. Kondisi demikian menyebabkan mempercepat lajunya proses karbonansi, sehingga material lempungan beserta kandungan fragmen organik seperti tulang binatang tampak berwarna hitam.

Bukti-bukti lapisan yang tersingkap menunjukkan bahwa proses sedimentasi berlangsung mulai dari lapisan pasir lempungan berwarna coklat kehitaman, kekompakan sedang, porositas sedang, dan semen pengikat antarbutir berupa larutan $\mathrm{CaCO}_{3}$ dan berstruktur lapisan massif. Fragmen-fragmen tulang tersementasi baik, akibat dari larutan $\mathrm{CaCO}_{3}$ yang datang baik dari atap gua maupun stalagtit. Penampakan-penampakan 
lapisan pasir lempungan ini menunjukkan bahwa proses pengendapan yang berlangsung pada kondisi lingkungan sekitar gua beriklim basah dan kelembaban tinggi. Pengendapan sedimentasi tersebut melalui media angin, sedangkan pengaruh air permukaan yang masuk ke dalam gua berdampak setelah pengendapan berlangsung.

Kelembaban yang cukup tinggi dengan sistem hidrologi yang buruk membuat penggenangan di dalam gua. Secara regional, ada kemungkinan sifat klimatologi beriklim basah terjadi. Hal tersebut mempengaruhi kondisi lingkungan di sekitar gua. Selain itu, mempengaruhi juga keberadaan hewan di sekitar yang berkembang dengan baik. Akibatnya lingkungan sekitar menumbuhkembangkan tumbuhan berukuran besar dan tinggi dengan subur, sebagai sumber pangan hewan. Dengan kata lain, bahwa keberadaan hewan berukuran besar seperti Bovidae, Boss, dan Cervidae, mampu hidup dan berkembang biak. Kondisi tersebut juga menguntungkan bagi manusia masa itu karena bahan pangan hewani dan tumbuhan cukup tersedia. Proses pengendapan sedimentasi lapisan pasir lempungan terhenti, kemudian dilanjutkan dengan lapisan pasir lanauan.

Lapisan pasir lanauan mengendap di bagian atas, sebagai lapisan penutup atau cap soil yang menyebabkan kondisi lapisan di bagian bawah menjadi aerobic. Hal tersebut berakibat proses oksidasi dan karbonasi pada lapisan pasir lempungan yang mengandung humus berjalan cukup baik. Akibatnya lapisan pasir lempungan tampak berwarna hitam.

Pengendapan selanjutnya adalah lapisan pasir lanauan berwarna coklat kemerahan, kekompakan sedang, porositas sedang, dan semen pengikat antarbutir berupa larutan $\mathrm{CaCO}_{3}$. Beberapa tempat memperlihatkan adanya gejala penggumpalan (blocky) agak membulat yang berukuran diameter $5 \mathrm{~cm}$ dan berstruktur lapisan massif. Penampakan-penampakan lapisan pasir lanauan ini menunjukkan, bahwa proses pengendapan yang berlangsung, pada kondisi lingkungan sekitar gua beriklim agak basah dan kelembaban sedang. Pengendapan sedimentasi lapisan pasir lanauan terhenti, kemudian dilanjutkan dengan proses pengendapan lapisan pasir halus yang bercirikan berwarna coklat kemerahan, kekompakan sedang, kelembaban sedang, dan porositas sedang.

Struktur perlapisan sedimen yang tampak adalah massif, sedangkan struktur tanah rounded (butiran). Ciri-ciri tersebut menunjukkan bahwa proses pengendapan material penyusun lapisan ini berlangsung pada lingkungan bertemperature rendah (musim kering) dan dibantu oleh media angin. Tampaknya proses sedimentasi berlangsung cukup lama karena sebaran horisontal di gua dari bagian mulut gua hingga ke belakang. Dapatlah diinterpretasikan bahwa pengendapan yang sedang berlangsung kondisi lingkungan sekitar bertemperatur rendah (kering). Tumbuhan tidak berkembang baik, sehingga populasi binatang pun terkena dampak berkurangnya populasi. Lingkungan bertemparatur rendah (musim kering) ini binatang-binatang yang berkembang biak dengan baik adalah jenis invertebrate (moluska) air tawar. Hal tersebut dikarenakan daerah ini banyak mengandung sungai, baik intermenten maupun sungai sepanjang tahun. Hewan sungai yang banyak dikonsumsi adalah kerang dan siput darat dan air tawar. Adanya pergantian temperatur lingkungan dari rendah (musim kering) ke lingkungan bertemperatur tinggi (musim basah) menyebabkan sedimentasi material berubah menjadi lapisan pasir kasar. Ciri-ciri lapisan pasir kasar berwarna coklat keabuan, kekompakan sangat jelek, dan tingkat porositasnya tinggi. Struktur sedimen yang tampak masif, sedangkan tekstur terbuka, dan struktur tanahnya rounded (membutir). Sifat-sifat yang ada di lapisan menunjukkan bahwa pengendapan berlangsung di lingkungan bertemperatur tinggi atau musim basah yang dibantu oleh dominasi media angin. Selain itu pula adanya pengaruh air yang keluar dari langit-langit gua melalui stalagtit menyebabkan pengendapan larutan $\mathrm{CaCO}_{3}$ di beberapa lapisan ini, terutama di bagian atas. Kondisi gua dan sekitarnya tidaklah terlalu berbeda, iklim lingkungan tampaknya lembab. Tumbuhan dan hewan berkembang baik, sehingga ketersediaan akan konsumsi manusia pendukung gua pun terpenuhi dari masa ke masa. Sebaran pengendapan sedimentasi secara horisontal berlangsung sampai bagian 
belakang gua. Sampai saat ini proses pengendapan tersebut masih berlangsung di dalam gua yaitu berupa pasir halus, berwarna coklat muda, semen karbonatan, porositas sangat baik, dan kekompakan sangat rendah. Tekstur lapisan sangat terbuka dengan struktur Korelasi antarlapisan dapat dilihat pada gambar berikut.

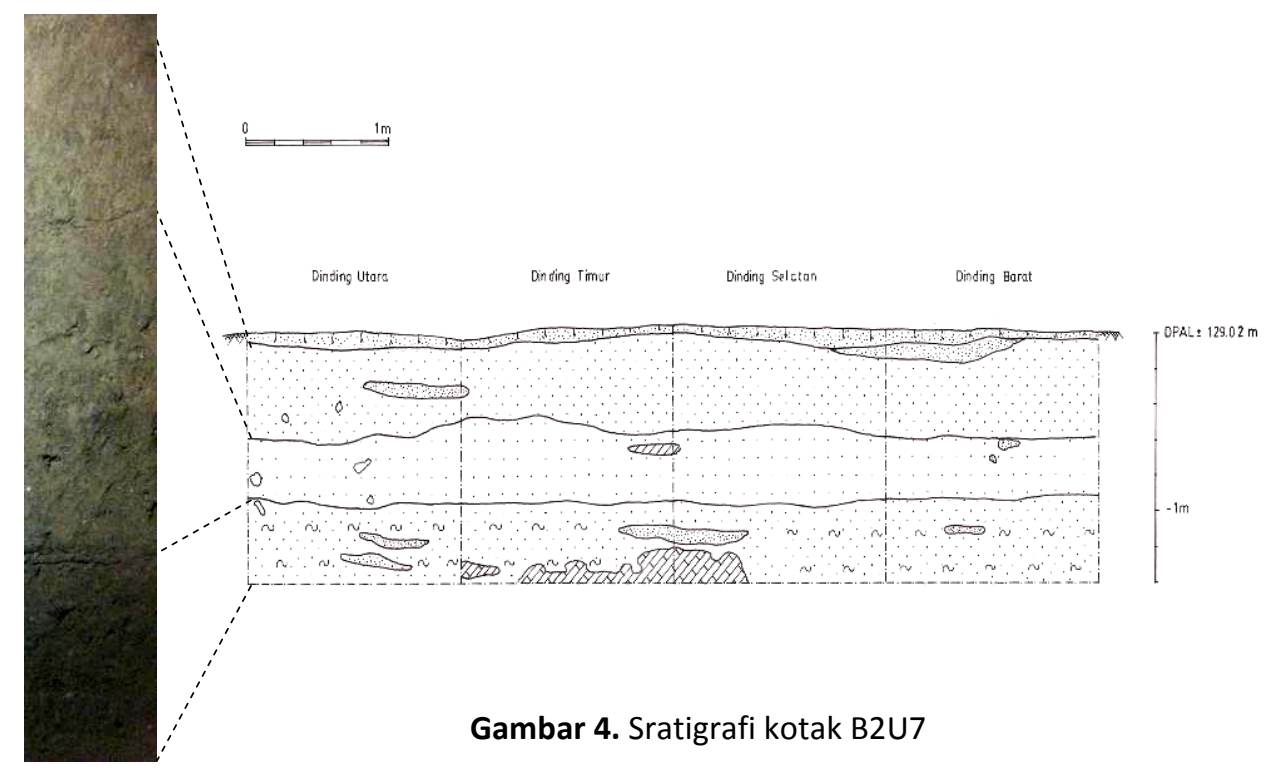

\section{JELAJAH RUANG DAN WAKTU PENGHUNI GUA KIDANG}

Berdasarkan uraian bab-bab di atas, dapat dirumuskan interpretasi dan dugaan atau hipotesis dalam menjawab beberapa permasalahan yang telah dirumuskan. Interpretasi yang dapat dirumuskan meliputi jangkauan jelajah manusia penghuni gua Kidang dalam mencari sumber makanan dan bahan baku untuk pembuatan peralatan sehari-hari dan pertanggalan geologis dan korelasi fauna antara gua Kidang dengan situs-situs kala Pleistosen (manusia purba).

\section{Jangkauan Jelajah Ruang Manusia Penghuni Gua Kidang}

Hasil ekskavasi selama enam tahap pada gua Kidang, semakin menegaskan bahwa gua Kidang merupakan hunian yang intensif dimanfaatkan untuk aktivitas seharihari dalam waktu lama. Pola hidup yang masih sepenuhnya mengandalkan potensi sumberdaya alam sekitarnya, baik untuk sumber makanan maupun sumber bahan baku untuk pembuatan peralatan sehari-hari akan tercermin dari tinggalan arkeologis. Tinggalan manusia penghuni gua Kidang baik berupa artefak maupun ekofak menunjukkan seberapa jauh jelajah manusia mengeksplorasi lingkungan alam sekitar dalam mempertahankan hidupnya. Manusia penghuni gua Kidang telah mengeksplorasi alam dalam mempertahankan hidupnya dengan pola adaptasi penjadwalan musim dalam mengkonsumsi pangan. Selain itu, beberapa lokasi telah dikelola sebagai sumber pangan dan sumber bahan baku untuk peralatan.

Batu rijang meskipun hanya sebagai bahan baku penunjang dalam ekosistem pola hidup manusia penghuni gua Kidang, namun keberadaan batu rijang tidak dapat diabaikan begitu saja. Hal tersebut disebabkan batu rijang merupakan bahan baku yang dibutuhkan dalam kehidupan sehari-hari. Sumber bahan baku batu rijang terdekat diduga berada di Bengawan Solo, berjarak sekitar 30 - $40 \mathrm{~km}$. Jika dugaan ini benar, maka jelajah manusia pendukung gua Kidang beradius 30 sampai dengan $50 \mathrm{~km}$. Untuk lebih dapat menginterpretasikan sejauh mana daya eksplorasi manusia prasejarah gua ini, maka diperlukan survei dan penelitian lebih lanjut. Terutama pada lokasi-lokasi yang 
berada di antara gua Kidang dengan daerah pantai (sumber makan) ataupun Bengawan Solo (sumber bahan baku alat).

Di lain pihak berdasarkan temuan fragmen gigi stegodon dan elephas di kotak B2U7, kemungkinan luasan daerah jelajah tidak hanya sampai pada daerah aliran Bengawan Solo purba saja, tetapi mencapai daerah Pegunungan Muria selatan (Nurani dan Hascaryo, 2011). Pegunungan Muria selatan merupakan lokasi situs Patiayam dengan berbagai temuan arkeologis dan paleontologis antara lain artefak litik dan fosil stegodon dan elephas (Setiawan, 2001). Jika dikorelasikan dengan temuan paleontologis gua Kidang berupa geligi stegodon dan elephas dapat diinterpretasikan adanya hubungan antara kedua situs tersebut.

Sangatlah menarik jika dicermati kondisi lingkungan purba situs Patiayam pada 800.000 tahun yang lalu. Penelitian geologi menunjukkan adanya perubahan lingkungan. Masa perubahan lingkungan diakibatkan perubahan iklim global antara interglasiasi dan glasiasi (Sartono, 1978). Kondisi interglasiasi dengan terjadi pencairan es mengakibatkan muka air laut mengalami kenaikan, sehingga terjadi penggenangan di daerah antara daratan Pulau Jawa bagian utara dengan Pegunungan Muria. Sebaliknya, terjadi susut laut pada masa glasiasi yang memunculkan daratan di daerah antara tersebut. Walaupun terjadi genangan laut, daerah ini masih dalam katagori laut dangkal. Kondisi paleolingkungan demikian memungkinkan untuk terjadi penjelajahan baik hominid maupun binatang-binatang.

Di lain pihak jika jangkauan jelajah tersebut benar, maka beberapa situs Pleistosen di Blora bagian tenggara yang merupakan situs-situs di DAS Solo yaitu situs Jigar, Manden, dan Ngandong juga merupakan jangkauan manusia gua Kidang. Hal tersebut menarik untuk dikaji lebih lanjut mengingat secara periodik situs-situs tersebut merupakan situs sebelum berkembangnya kehidupan di gua atau ceruk. Apakah manusia penghuni gua Kidang merupakan kelanjutan dari manusia purba yang hidup masih mengembara di DAS Solo? Apabila jawabannya iya, maka evolusi manusia Jawa akan terangkai tanpa putus dari manusia purba menuju manusia prasejarah. Selain itu di bagian selatan gua Kidang terdapat situs manusia purba Sangiran. Titik-titik pinggiran radius $30-50 \mathrm{~km}$ tersebut menunjukkan situs-situs manusia purba dengan budayanya yang berkembang sebelum kehidupan di gua. Untuk menjawab semua itu, diperlukan penelitian lebih mendalam yang melibatkan berbagai disiplin ilmu, sehingga kesinambungan budaya dari manusia purba (Kala Plestosen) menuju manusia prasejarah (Kala Holosen) akan terjawab.

Berdasarkan hasil penelitian tahap enam (2012), maka interpretasi dan dugaan jangkauan jelajah manusia penghuni gua Kidang semakin jelas. Sebagaimana telah diuraikan pada bagian sebelum ini hasil survei di teras sungai Lusi, memberikan informasi yang menarik. Hal tersebut terkait dengan temuan situs baru yang mengandung jejakjejak aktivitas manusia purba kala Pleistosen. Potensi arkeologis teras sungai Lusi adalah dengan ditemukannya berbagai fosil hewan dan artefak. Berdasarkan berbagai temuan di teras Sungai Lusi tersebut, memperkuat interpretasi sebelumnya, bahwa Gua Kidang mampu memberikan kejelasan missing link antara budaya dan evolusi manusia dari kala Pleistosen sampai dengan kala Holosen. Jejak stratigrafi pada kotak B2U7 mempertajam dugaan ini, yaitu dengan ditemukan lapisan yang mengandung evolusi jenis hewan. Lebih lanjut interpretasi ini akan diperjelas berdasarkan kajian geologis pada bagian B di bawah ini.

\section{Pertanggalan Geologi dan Fauna Vertebrata Gua Kidang dan Teras Sungai Lusi, Kabupaten Blora (Korelasi Umur Relatif)}

Gua Kidang mulai banyak dikenal dan dipublish di media massa sejak ditemukannya rangka utuh manusia prasejarah satu konteks dengan temuan artefak tulang dan kerang. Penemuan yang sangat signifikan berupa rangka manusia (Homo sapiens) utuh posisi semi terlipat dan tinggalan arkeologis masa pre neolotik 7.000-8.000 BP (Nurani dan Agus Tri Hascaryo, 2011). Selain itu, berdasarkan hasil eksplorasi 
pemanfaatan lingkungan prasejarah, ditemukannya situs baru yang memiliki kandungan data arkeologis cukup menarik untuk dikaji lebih lanjut. Situs ini merupakan situs terbuka yang berada di teras daerah aliran Sungai Lusi.

Berdasarkan temuan Homo sapiens di gua Kidang dan situs baru di teras sungai Lusi, dapat dirumuskan suatu hipotesis konteks kronologi relatif terkait dengan permasalahan dalam tulisan ini (jelajah waktu). Hal tersebut diharapkan untuk memperjelas gambaran evolusi budaya manusia yang pernah ditemukan di Pulau Jawa. Data konteks korelasi yang digunakan didasarkan pada temuan arkeologis, geologis, dan paleontologist dari situs-situs gua Kidang, teras Bengawan Solo, Pati Ayam, serta Sangiran. Hipotesis yang terumuskan adalah terdapat hubungan evolusi kebudayaan manusia dari keempat situs tersebut. Homo erectus yang ditemukan di situs Ngandong berumur antara $500 \pm 12$ ka (Indriati, 2011). Evolusi dan adaptasi pada lingkungan terbuka seperti padang rumput Afrika. Antara 200.000 - 60.000 BP terjadi perubahan lingkungan menjadi hutan agak terbuka yang menyebabkan evolusi Homo erectus menjadi seperti Pongo pygmaeus ditemukan pada Situs Punung. Kemudian perubahan lingkungan berubah ke hutan terbuka yang diikuti oleh perubahan evolusi Homo erectus ke arah Homo sapiens, terbukti oleh Homo Wajakensis di situs Campur Darat - Besole berusia 6.500 tahun yang lalu. Lebih jauh, Nurani berdasarkan dating carbon C14 menghasilkan pertanggalan sekitar $7.000-8.000$ BP (Nurani dan Agus Tri Hascaryo 2011). Hal ini menarik untuk dilakukan korelasi evolusi hasil tinggalan budaya kala Pleistosen hingga Holosen.

Data artefak berupa alat tulang, batu asah tulang, alat kerang, dan rangka manusia dari situs gua Kidang, memiliki nilai penting bagi ilmu pengetahuan terhadap situs-situs sekitar perbukitan karst Blora. Keberlanjutan teori evolusi memungkinkan untuk dikaji lebih jauh yaitu membandingkan temuan-temuannya. Artinya bahwa korelasi umur relatif dapat dilakukan pada keempat situs yang terdekat dengan situs gua Kidang, seperti terlihat pada peta konteks catchment area situs gua Kidang dengan situs-situs Pleistosen berikut di bawah.

Situs-situs perbukitan karst Blora, secara tektono-fisiografis Jawa, terletak pada Zona Tinggian Pegunungan Utara (Bemmelen, 1949). Lingkungan zona ini terbentang di selatan Pulau Jawa bagian utara, yang terbentuk pada kala Miosen Awal dan membujur arah timur-barat. Fasies pembentukan batugampingnya terdiri dari empat fasies yaitu fasies packstone, floatstone, rudstone, dan boundstone. Fasies-fasies tersebut mempengaruhi tingkat kekompakan batugamping yang berdampak pada tingkat pembentukkan gua. Semakin tinggi tingkat kekompakannya maka semakin tinggi pula pembentukan guanya. Hal ini akan mempengaruhi pola jenis gua-gua yang ada hingga topografi karst. Proses pengangkatan dan penyusutan air laut bagian utara pulau Jawa pada masa Pleistosen menyebabkan munculnya satuan batuan gamping menjadikan daratan-daratan Zona Rembang yang membujur timur-barat dengan variasi morfologinya. Bukit-bukit gamping yang berbatasan dengan lembah ataupun danau di sekitar perbukitan berkembang mengikuti proses morfogenetisnya. Sementara itu, bagian tengah Pulau Jawa yang berumur lebih tua telah mengalami pengangkatan terlebih dahulu membentuk antiklinoriun daratan Zona Kendeng, Zona Muria-Patiayam bagian utara, dan Depresi Randublatung (periksa gambar zona-zona fisiografi).

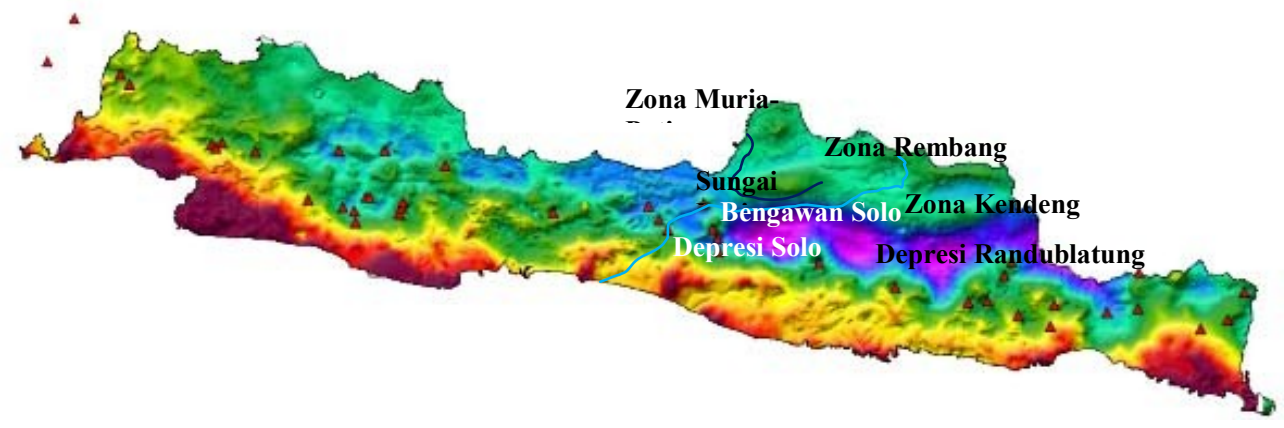

Gambar 5. Zona-zona Fisiografi Pulau Jawa Bagian Timur 


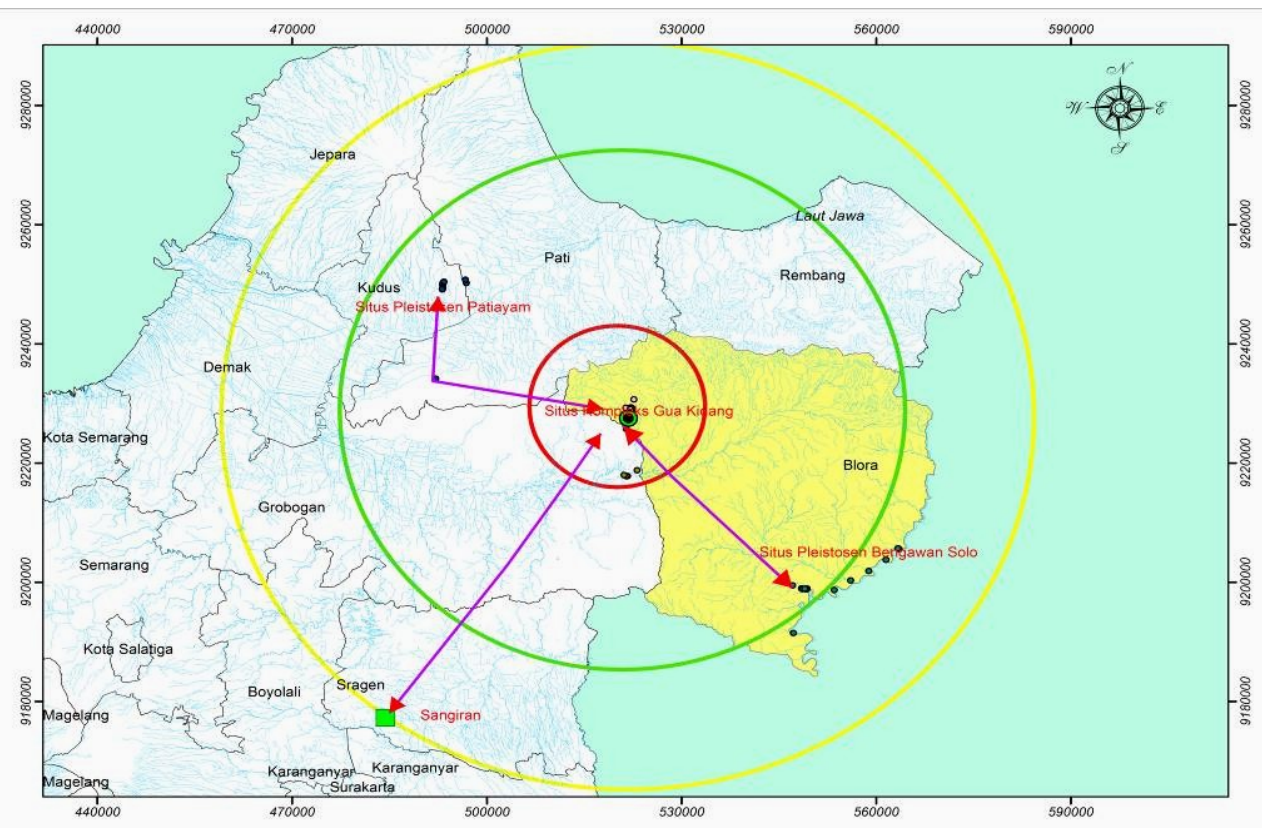

Gambar 6. Konteks Catchment Area Situs Gua Kidang dengan Situs-situs Pleistosen

Perkembangan morfogenetis zona ini membentuk variasi topografi lembah sungai dan tinggian-tinggian perbukitan lipatan. Muncul dan proses eksogen yang membentuk satuan-satuan morfogenetik telah dimulai sejak kala Pleistosen, terbukti dengan pembentukkan Formasi Kabuh berumur Pleistosen bawah hingga atas. Lingkungan pengendapannya pun menunjukkan terjadi pada daerah daratan dengan variasi sungaisungainya. Tampak pada struktur sedimen berupa silang siur di formasi ini membuktikan adanya media sungai membawa material endapan. Sebagai daratan yang memiliki sumber-sumber air sungai tentunya menjadi tempat layak huni bagi makhluk hidup, baik hewan maupun manusia. Temuan arkeologis dan paleontologis Formasi Kabuh dan Notopuro di Situs Sangiran berupa Homo erectus, Bovidae (kerbau, sapi, banteng), Cervidae (Rusa), Stegodon, Elephas (gajah purba), Rhinocerus (badak), Hippopotamus (Kuda Nil), Susbrachygnathus Dubois (Babi), Bibospalaeosondaicus (Banteng), Canidae (Anjing), Felis Paleojavanica (Harimau).

Perkembangan selanjutnya, daratan utara Jawa membentuk Zona Rembang yang tersusun oleh satuan batuan batugamping mulai mengalami proses karstisasi. Pembentukan gua-gua karst sebagai evolusi genetic mulai masa Pleistosen Tengah dengan membentuk lorong sungai bawah permukaan. Pengangkatan terus berlangsung hingga masa Pleistosen awal mengakibatkan pembentukan gua semakin intensif. Variasi gua bukan lagi hanya sekedar lorong namun gua karst ini telah memiliki ruang-ruang berukuran tertentu, lantai bertanah, dan tinggi atap tertentu pula.

Selain pengangkatan dan proses eksogenik yang membentuk topografi karst di Zona Rembang tampak pula pembentukan daerah aliran sungai permukaan pada masa pliosen - pleistosen awal. Terbentuknya sungai Lusi adalah salah satu bukti eksogenik berlangsung di daerah ini. Sungai ini termasuk jenis sungai yang berair sepanjang tahun walaupun mengalami penyusutan volume air di musim kemarau dan peningkatan volume di musim penghujan. Artinya, bahwa sejak masa Pleistosen tengah, kemungkinan daerah sekitar aliran sungai sudah dapat digunakan sebagai tempat hidup baik binatang maupun manusia. Teras-teras sungai Lusi dan lapisan grenzbank menunjukkan adanya proses eksogenik yang terus berlangsung hingga saat ini. Tinggalan masa lampau atau bukti arkeologis dan antropologis berupa fragmen tulang buffelus bubalus, cervidae, geoselon, bos, gigi hiu, alat batu rijang, alat batu andesit, dan lancipan tulang. Hal yang menarik dengan temuan tersebut bukan hanya pertama kali ditemukannya tinggalan arkeologis- 
paleontologis di sungai Lusi yang berada di antara Bengawan Solo dan Zona Rembang tetapi patut untuk dikaji konteks hubungan kronologisnya.

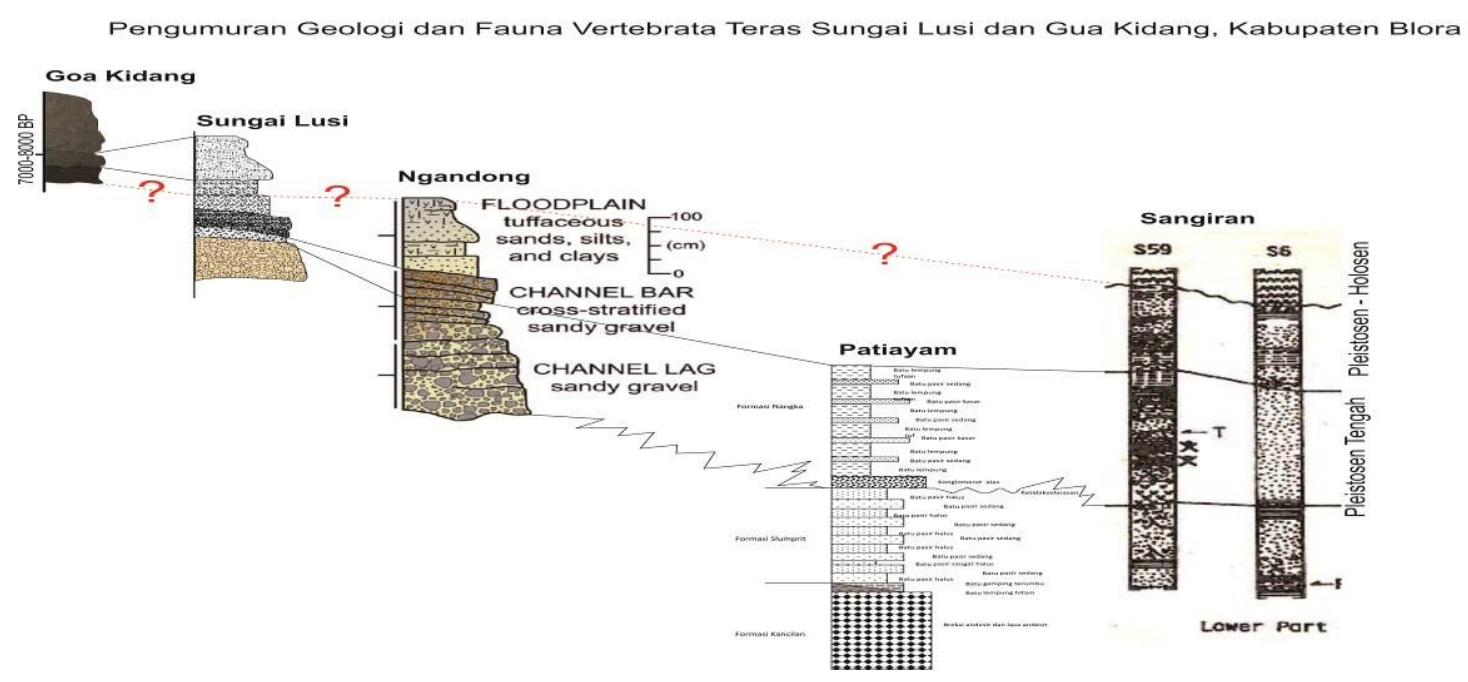

Gambar 7. Korelasi Kronologis Relatif Situs Gua Kidang dengan Situs-situs Pleistosen

Atas dasar temuan-temuan arkeologis dan paleontologis yang berada di dalam lingkaran catchment area menunjukan kemungkinan dapat dilakukan korelasi umur relatif. Tingkatan ini baru sampai pada evolusi awal yang mencoba menghubungkan secara kronologisnya. Tampak pada situs berumur Pleistosen seperti Situs Sangiran menunjukkan temuan arkeologis yang lebih tua dibandingkan dengan situs-situs di teras Bengawan Solo seperti Situs Ngandong. Bagian utara Pulau Jawa terdapat situs-situs berumur Pleistosen yaitu Situs Patiayam dengan temuannya binatang stegodon, elephas, cervidae, dan bos dapat sebagai petunjuk konteks hubungan antara situs-situs tersebut. Posisi kronologis Situs Gua Kidang dan Sungai Lusi pada relung evolusi sangat menarik untuk dikaji lebih dalam. Hal ini dikarenakan temuan vertebrata di Gua Kidang pada kotak ekskavasi B2U7 kedalaman $150 \mathrm{~cm}$ menunjukkan tanda-tanda fosilisasi tingkat menengah atau sub fosil pada temuan tulang vertebratanya. Lapisan tanah di kedalaman ini juga menunjukkan adanya proses karbonasi sehingga tampak berwarna hitam. Temuan-temuan tersebut kemungkinan akan lebih bervariatif jika dilakukan pendalaman. Di lain pihak, temuan permukaan sungai Lusi menunjukkan sifat fosilisasi sub fosil namun pada teras bawah menunjukkan adanya proses fosilisasi tingkat menengah. Ketertarikan untuk menghubungkan kronologis antara situs-situs dalam lingkar catchment area adalah adanya temuan artefaktual yang memungkinkan untuk mengetahui hubungan evolusi budaya. Lebih lanjut dapat dilihat gambar di bawah, korelasi kronologis relatif situs gua Kidang dengan situs-situs Pleistosen.

\section{PENUTUP}

Berdasarkan uraian bab-bab di atas, maka dapat disimpulkan adanya dua dugaan, yaitu sebagai berikut.

1. Jangkauan jelajah manusia penghuni gua Kidang dalam mempertahankan hidupnya berdasarkan temuan ekskavasi menjangkau sejauh $50 \mathrm{~km}$. Jangkauan jelajah sejauh itu didasarkan pada temuan artefak batu (rijang) yang sumber bahan bakunya berada di DAS Solo. Selain itu juga, didasarkan temuan species elephas dan stegodon yang habitatnya berada di daerah Pegunungan Muria (situs Pati Ayam). Lebih lanjut berdasarkan survei pada teras sungai Lusi menunjukkan adanya korelasi stratigrafi dengan didukung temuan fragmen binatang sub fosil yang semasa dengan Gua Kidang, maka terdapat jangkauan 
yang lebih dekat dari situs-situs Pleistosen di atas. Akibatnya terdapat tiga ring jangkauan manusia Gua Kidang dalam bereksplorasi mencari sumber pangan dan sumber bahan baku untuk peralatan sehari-hari.

2. Berdasarkan survei di teras Sungai Lusi yang merupakan temuan situs baru, korelasi antara gua Kidang dengan situs-situs kala Pleistosen (DAS Solo, Pati Ayam, dan Sangiran) semakin jelas. Pertanggalan relatif yang didukung temuan arkeologis di kelima situs dapat disimpulkan adanya kesinambungan baik budaya maupun manusia sejak kala Pleistosen sampai kala Holosen. Bukti stratigrafi di kotak B2U7 pada lapisan 4 menunjukkan adanya lapisan yang selaras dengan stratigrafi di teras Sungai Lusi. Sementara itu, data hominid juga memberikan informasi yang lebih jelas perkembangannya dari Homo erectus ke Homo sapiens. Diharapkan berdasarkan beberapa kejelasan permasalahan terkait kesinambungan budaya kala Pleistosen ke kala Holosen yang selama ini masih missing link akan terungkap dari Situs Gua Kidang. Hunian awal (lapisan terbawah) di Gua Kidang besar kemungkinan akan menjawab missing link tersebut.

\section{KEPUSTAKAAN}

Bemmelen, R.W. van, 1970, The Geology of Indonesia Vol IA, 2nd edition, Martinus Nijhoff, The Hague.

Gunadi Dkk., 2007. "Ekskavasi Situs Kuwung, Kec. Kradenan-Kab. Blora”, Laporan Penelitian Arkeologi, Kerjasama Pemerintah Kabupaten Blora dan Balai Arkeologi Yogyakarta.

Gunadi Dkk. 2008. "Eksplorasi Sumberdaya Arkeologi di Kawasan Blora Bagian Selatan", Laporan Penelitian Arkeologi, Kerjasama Pemerintah Kabupaten Blora dan Balai Arkeologi Yogyakarta.

Indriati, Etty et. al., 2011, "The Age of the 20 Meter Solo River Terrace, Java, Indonesia and the Survival of Homo erectus in Asia, PLoS one, www.plosone.org, Volume 6, Issue 6, e21562, USA.

Moelyadi, 1984. Sedimentasi dan Posisi Stratigrafi Fosil Elephas pada Formasi Kabuh di Daerah Mulyorejo, Cepu, Jawa Tengah. Yogyakarta: Jurusan Teknik Geologi Fakultas Teknik, UGM.

Nurani, Indah Asikin dan J. Susetyo Edy Yuwono, 2005. LPA Pola Okupasi Gua-gua Hunian Prasejarah Kawasan Pegunungan Utara Jawa di Kabupaten Blora Tahap I. tidak terbit

, 2008. "Gua Kidang, Pilihan Manusia Prasejarah Di Kawasan Karst Blora" Berkala Arkeologi Edisi Mei (1). Yogyakarta: Balai Arkeologi, hlm 1-20.

Nurani, Indah Asikin dan Agus Tri Hascaryo, 2011. LPA Pola Okupasi Gua Hunian Prasejarah Kawasan Karst Blora di Gua Kidang. Tidak terbit

Nurani, Indah Asikin, Agus Tri Hascaryo, dan Toetik Koesbardiati, 2012. LPA Pola Okupasi Gua Kidang, Hunian Prasejarah Kawasan Karst Todanan, Blora. Tidak terbit 
Sartono, 1978. Sedimentasi Daerah Patiayam Jawa Tengah. Jakarta: PT Rora Karya.

Setiawan, Andry, 2001. "Geologi dan Paleontologi Vertebrata Daerah Patiayam dan Sekitarnya di Kecamatan Jekulo, Kabupaten Kudus Jawa Tengah". Skripsi Departemen Teknik Geologi - Fakultas IImu Kebumian dan Teknologi Mineral. ITB

Soejono, R.P., 2000. Sejarah Nasional Indonesia Jilid 1. Jakarta: Balai Pustaka 